\title{
Cytological Observations on Some South Indian Ferns
}

\author{
P. I. Kuriachan \\ Department of Botany, Kerala University, Trivandrum, India
}

Received March 25, 1967

An extensive survey of the Pteridophyte flora of South India was started a few years back in the Department of Botany, Kerala University, Trivandrum and the cytological data relating to more than 150 species of South Indian Pteridophytes were reported earlier (Abraham and Ninan 1954, 1958, 1965, Abraham et al. 1962, Ninan 1955, 1956 a-e, 1958 a-c, Kuriachan 1963, 1965). It has been possible to investigate the cytology of 40 more taxa belonging to 32 species of leptosporangiate ferns and the important observations are presented here. Details regarding the various species will be reported elsewhere.

\section{Materials and methods}

Most of the species investigated during the present study were collected from hill stations in South India such as Aryankavu $(600 \mathrm{M})$, Courtallum $(650 \mathrm{M})$, Ponmudi (500-1050 M), Munnar (1500 M), Ootacamud (1500-2100M) and Kodaikanal (1800-2000 M). Some of the species were also collected from the plains of Kerala. A few garden materials of unknown wild origin were also studied. In making cytological preparations the usual acetocarmine squash and smear techniques were followed (Abraham et al. 1962).

\section{Observations}

Both meiotic and mitotic chromosomes were examined in most of the species studied. In a few cases, due to lack of suitable materials, either the meiotic or the somatic number alone could be studied. Details regarding the chromosome numbers in the materials investigated are given in Table 1.

Table 1. Chromosome numbers in some South Indian ferns

\begin{tabular}{|c|c|c|c|c|}
\hline \multirow{2}{*}{ Species } & \multirow{2}{*}{ Source } & \multicolumn{2}{|c|}{$\begin{array}{c}\text { Chromosome } \\
\text { number }\end{array}$} & \multirow{2}{*}{ Ploidy } \\
\hline & & $\mathrm{n}$ & $2 \mathrm{n}$ & \\
\hline $\begin{array}{l}\text { Trichomanes intramarginale } \\
\text { Hook \& Grev. } \\
T \text {. plicatum Bedd. } \\
\text { Dennstaedtia glabrescens } \\
\text { Ching } \\
\text { Microlepia platyphylla (Don.) } \\
\text { J. Sm. } \\
\text { Lindsaya cultrata Sw. } \\
\text { L. heterophylla Dryander } \\
\text { Pteridium aquilinium var. } \\
\text { wightianum (Wall.) Tryon } \\
\text { Idiopteris hookeriana } \\
\text { (Agardh) T.G. Walker }\end{array}$ & $\begin{array}{l}\text { Ponmudi hills } \\
\text { " } \\
\text { Trivandrum } \\
\text { Public Gardens } \\
\text { Perumal malai- } \\
\text { Kodaikanal } \\
\text { Bear Shola- } \\
\text { Kodaikanal } \\
\text { Ponmudi hills } \\
\text { " } \\
\text { Kodaikanal }\end{array}$ & $\begin{array}{r}43 \\
\text { ca. } 153 \\
86 \\
52\end{array}$ & $\begin{array}{r}182 \\
86 \\
- \\
- \\
104 \\
108\end{array}$ & $\begin{array}{c}\text { tetraploid } \\
\qquad " \\
\text { diploid } \\
\text { hexaploid } \\
\text { tetraploid } \\
\text { diploid } \\
\text { tetraploid }\end{array}$ \\
\hline
\end{tabular}




\begin{tabular}{|c|c|c|c|c|}
\hline Pteris ensiformis var. victoriae & $\begin{array}{l}\text { Trivandrum Public } \\
\text { Gardens }\end{array}$ & $\begin{array}{l}\text { irregular } \\
\text { meiosis }\end{array}$ & 87 & triploid \\
\hline P. ensiformis var. victoriae & $"$ & "110 & 84 & ca. triploid \\
\hline P. ensiformis var. victoriae & $"$ & 84 & 168 & ca. hexaploi \\
\hline P. multianrita Agardh & Ponmudi hills & 29 & 58 & diploid \\
\hline P. pellucida Presl. & $\begin{array}{l}\text { Muvattupuzha, } \\
\text { Parambikulam }\end{array}$ & 58 & 116 & tetraploid \\
\hline P. pellucida Presl. & Aryankavu & 29 & 58 & \\
\hline$P$. ottaria Bedd. & Ponmudi hills & 29 & 58 & diploid \\
\hline $\begin{array}{l}\text { Pellaea boivini Hooks } \\
\text { Adiantum macrophyllum } \mathrm{Sw} \text {. }\end{array}$ & Trivandrum & 30 & 60 & diploid \\
\hline & Public Gardens & 30 & 60 & diploid \\
\hline , capillus veneris L. cv. & $"$ & & 60 & diploid \\
\hline $\begin{array}{l}\text { A. polyphyllum Willd } \\
\text { Ceratopteris thalictroides (L.) }\end{array}$ & " & sterile & 120 & tetraploid \\
\hline Brongen. & Parambikulam & 38 & - & ca. dipl \\
\hline C. thalictroides (L.) Brongn. & Nilam & 76 & - & ca. te \\
\hline $\begin{array}{l}\text { C. thalictroides (L.) Brongn. } \\
\text { Nephrolepis multiflora }\end{array}$ & Veli-Trivandrum. & 80 & - & tetraploid \\
\hline (Roxb.) Jarret & The kady & 82 & 164 & " \\
\hline N. multiflora (Roxb.) Jarrett & $\begin{array}{l}\text { Lal Bagh Gardens- } \\
\text { Bangalore }\end{array}$ & - & 82 & diploid \\
\hline Doodia media R. Br. & Kodaikanal & 60 & 120 & tetraploid \\
\hline $\begin{array}{l}\text { Asplenium crinicaule Hance } \\
\text { A. evectum Bory }\end{array}$ & $\begin{array}{l}\text { Ponmudi hills } \\
\text { Bear shola- }\end{array}$ & 144 & - & octoploid \\
\hline A. formossum Willd & $\begin{array}{l}\text { Kodaikanal } \\
\text { Bear shola - } \\
\text { Kodaikanal, } \\
\text { Courtallum, } \\
\text { Palaruvi - } \\
\text { Aryankavu, }\end{array}$ & 36 & - & diploid \\
\hline A. indicum sledge & $\begin{array}{l}\text { Ponmudi hills } \\
\text { Bear shola and Fairy } \\
\text { falls-Kodaikanal, } \\
\text { Ponmudi hills }\end{array}$ & 36 & - & diploid \\
\hline A. normale Don. & $\begin{array}{l}\text { Pillar rocks - } \\
\text { Kodaikanal }\end{array}$ & 144 & - & diploid \\
\hline A. unilaterale Lam. & Munnar & 76 & ca. 152 & tetraploid \\
\hline $\begin{array}{l}\text { A. unilaterale Lam. v. vivale } \\
\text { Bedd. }\end{array}$ & $\begin{array}{l}\text { Pillar rocks - } \\
\text { Koodaikanal }\end{array}$ & 40 & - & diploid \\
\hline $\begin{array}{l}\text { Microsorium membranacium } \\
\text { (Don.) Ching }\end{array}$ & Kod & 36 & 72 & diploid \\
\hline M. pteropus (Bl.) Ching & Ponmudi hills & $\begin{array}{l}36 \\
\text { irregular }\end{array}$ & 72 & diploid \\
\hline$M$. pteropus (Bl.) Ching & Ootacamund & meiosis & 108 & triploid \\
\hline & $\begin{array}{l}\text { Lal Bagh Gardens- } \\
\text { Bangalore }\end{array}$ & 36 & 72 & diploid \\
\hline $\begin{array}{l}\text { Grammitis attenuata Kze. } \\
\text { Loxogramme involuta Presl. }\end{array}$ & $\begin{array}{l}\text { Ponmudi hills } \\
\text { Bear shola - } \\
\text { Kodaikanal }\end{array}$ & $\begin{array}{l}36 \\
70\end{array}$ & $\begin{array}{l}72 \\
-\end{array}$ & $\begin{array}{l}\text { diploid } \\
\text { tetraploid }\end{array}$ \\
\hline Vittaria elongata $\mathrm{Sw}$. & $\begin{array}{l}\text { Muvattupuzha, } \\
\text { Palode- }\end{array}$ & & & \\
\hline lata Aubl. & $\begin{array}{l}\text { Trivandrum } \\
\text { Veli-Trivandrum }\end{array}$ & $\begin{array}{c}120 \\
\text { irregular } \\
\text { meiosis }\end{array}$ & $\begin{array}{r}240 \\
45\end{array}$ & $\begin{array}{l}\text { octoploid } \\
\text { pentaploid }\end{array}$ \\
\hline
\end{tabular}

\section{Discussion}

During the present investigation the cytology of 40 taxa belonging to 32 species of South Indian ferns has been studied. This includes cytological informa- 

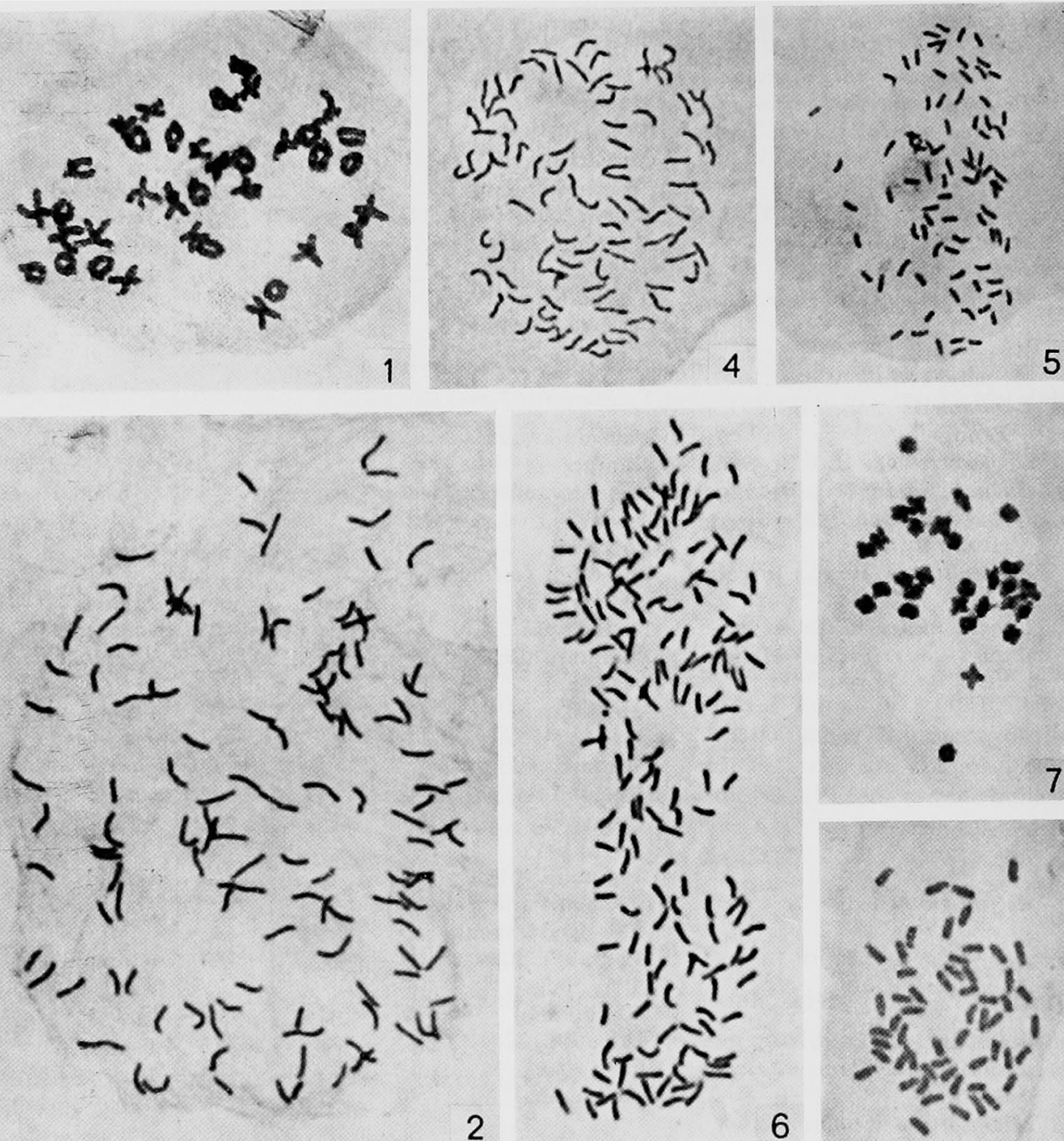

2

6

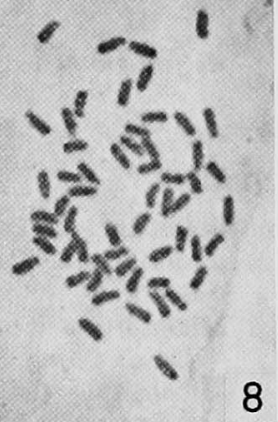

xey or
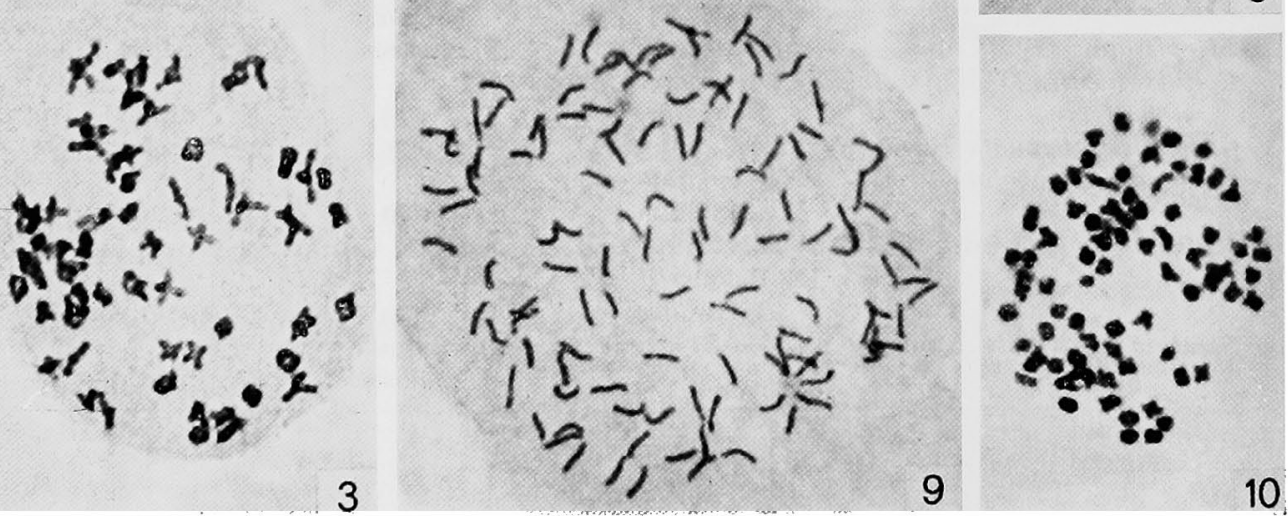

Figs. 1-10. $\times 750.1$, diakinesis in a spore mother cell of Grammitis attenuata showing 36 bivalents. mitotic metaphase in a root tip cell of Doodia media showing 120 chromosomes. 3 , diakinesis in a spore mother cell of $D$. media showing 60 bivalents. 4-6, mitotic metaphase in root tip cells 
tion on 11 species, on which there is no previous report and new chromosome counts on 13 taxa, for which other numbers have been reported from various geographic regions.

Data on chromosome numbers given in Table 1 show the existence of additional basic chromosome numbers in the genera Lindsaya, Pellaea, Ceratopteris, Doodia and Grammitis. Earlier reports of chromosome numbers show $n=29,58,87$, ca. 90 and 116 in Pellaea, $\mathrm{n}=40,76,77,78$ and 80 in Ceratopteris and $\mathrm{n}=37$ in Grammitis (see Chiarugi 1960 and Fabbri 1963, 1965). The present investigation has revealed the existnce of the haploid numbers $\mathrm{n}=30$ in Pellaea boivini, $\mathrm{n}=38$ in Ceratopteris thalictroides (Fig. 11) and $n=36$ in Grammitis attenuata (Fig. 1) which are new counts for the above genera. Previous reports (see Chiarugi 1960 and Fabbri 1963, 1965) indicate the presence of chromosome numbers like $\mathbf{n}=34,82$, 47, 150 and 155 in Lindsaya. Based on these numbers, Fabbri (1965) has suggested $34,41(?), 47$, and ca. 50 as possible basic numbers in this genus. The present finding of $\mathbf{n}=\mathbf{8 6}$ in Lindsaya heterophylla which is the first report in this species suggests the possibility of yet another basic number $(x=43)$ for the genus. Brownlie (1961) has reported $n=64$ in Doodia media. The present finding of $n=60$ and $2 n=120$ (Figs. 3 and 2 ) in Doodia media indicates the possibility of a new basic number $(x=30)$ for the genus.

The occurrence of more than one cytotype has been encountered in Pteris ensiformis var. victoriae, $P$. pellucida, Asplenium unilaterale, Ceratopteris thalictroides and Microsorium pteropus. Different clones of Pteris ensiformis var. victoriae investigated during the present study showed somatic chromosome numbers like $2 n=87$ (Fig. 4), $2 n=84$ (Fig. 5) and $2 n=168$ (Fig. 6). Materials of Pteris pellucida collected from Aryankavu were diploids with $\mathrm{n}=\mathbf{2 9}$ and $2 \mathrm{n}=\mathbf{5 8}$ (Figs. 7 and 8). Two other collections of the same species obtained from Parambikulam and Muvattupuzha were tetraploids with $n=58$ and $2 n=116$ (Fig. 9). Asplenium unilaterale showed two cytotypes with $\mathrm{n}=40$ and $\mathrm{n}=76$ (Fig 10) respectively. Chromosome numbers like $n=38$ (Fig. 11), $n=76$ and $n=80$ (Fig. 12) were met with in materials of Ceratopteris thalictroides collected from different places. Two distinct cytotypes, a diploid with $n=36$ and $2 n=72$ (Fig. 13) and a triploid with $2 \mathrm{n}=108$ (Fig. 14) of Microsorium pteropus were also investigated.

Irregular meiotic behaviour suggesting possible hybrid origin has been observed in Pteris ensiformis, Microsorium pteropus and Salvinia auriculata with $2 \mathrm{n}=45$ (Figs. 15 and 16). Adiantum polyphyllum was found to show complete sterility and in all likelihood is of hybrid origin. While these species are incapable of sexual

of Pteris ensiformis var. victoriae. 4, $2 \mathrm{n}=87$ (Trivandrum Public Gardens). 5, 2n=84 (Trivandrum Public Gardens). 6, 2n=168 (Trivandrum Public Gardens). 7-9, meiotic and mitotic chromosomes in Pteris pellucida. 7, metaphase I in a spore mother cell showing 29 bivalents (Aryankavu). 8, mitotic metaphase 7, in a root tip cell showing 58 chromosomes (Aryankavu). 9, mitotic metaphase in a root tip cell showing 116 chromosomes (Muvattupuzha). 10, metaphase I in a spore mother cell of Asplenium unilaterale showing 76 bivalents. 


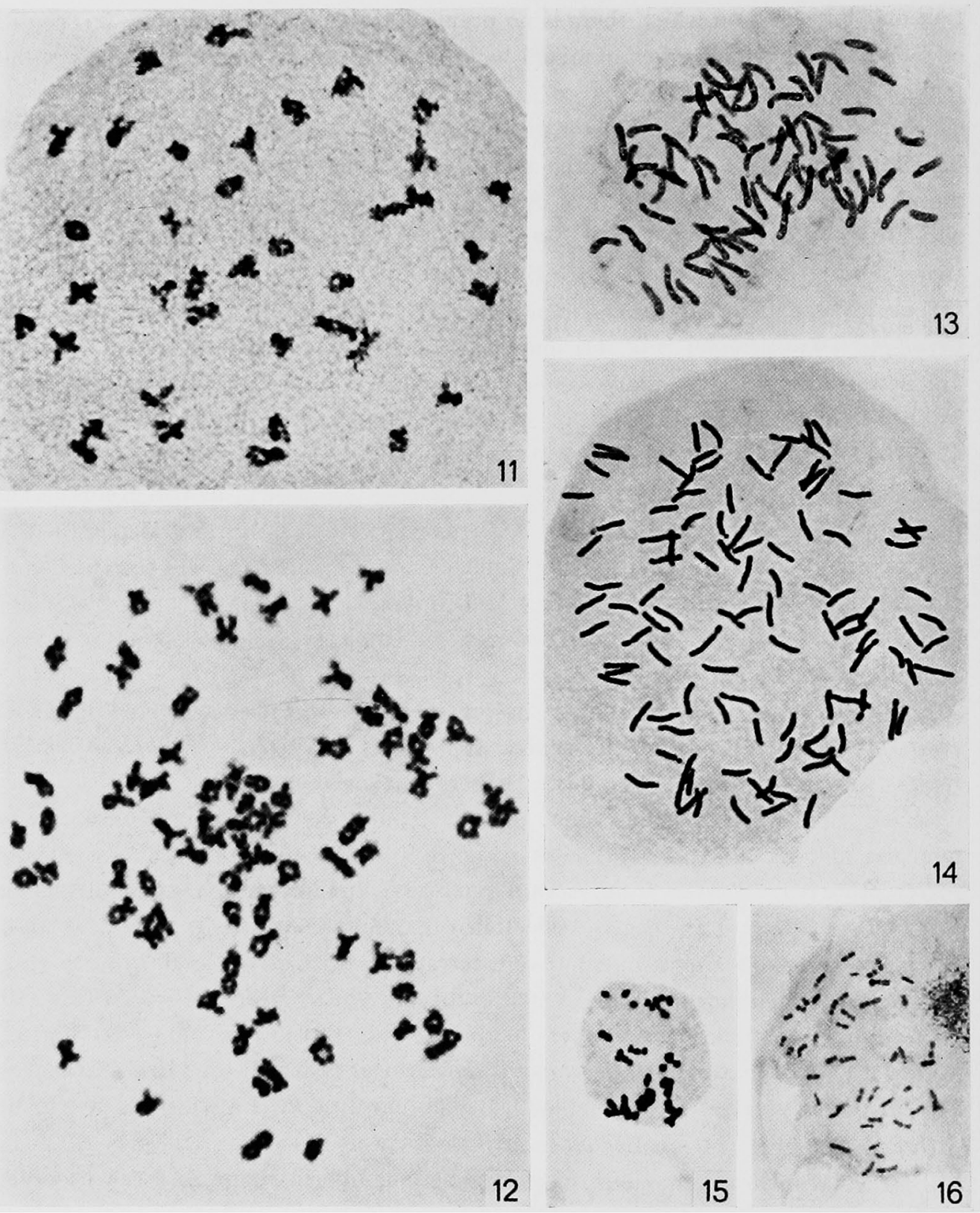

Figs. 11-16. $\times$ 750. 11-12, diakinesis in spore mother cells of Ceratopteris thalictroides. 11, $\mathrm{n}=38$ (Parambikulam). 12, $\mathrm{n}=80$ (Veli). 13-14, mitotic metaphase in root tip cells of Microsorium pteropus. 13, 2n= 72 (Ponmudi hills). 14, 2n=108 (Oottacamund). 15-16, meiotic and mitotic chromosomes in Salvinia auriculata. 15, irregular meiosis in a spore mother cell. 16, mitotic metaphase showing 45 chromosomes.

reproduction, they propagate vegetatively through rhizomes. This may provide an explanation for the occurrence of a good number of natural hybrids among present day ferns. 


\section{Summary}

Cytological observations on 40 taxa of South Indian ferns belonging to 32 species were made. Eighteen of these are diploids and the others show various levels of polyploidy (triploid to octoploid).

Haploid chromosome numbers like $n=30, n=38$, and $n=36$ were observed in Pellaea boivini, Ceratopteris thalictroides and Grammitis attenuata respectively, which are new reports for these three genera. Evidences of new basic numbers like $\mathrm{x}=43$ and $\mathrm{x}=30$ were also obtained in the genera Lindsaya (L. heterophylla, $\mathrm{n}=86$ ) and Doodia (D. media, $\mathrm{n}=60,2 \mathrm{n}=120$ ) respectively.

The occurrence of more than one cytotype has been demonstrated in Pteris ensiformis v. victoriae, P. pellucida, Ceratopteris thalictroides, Asplenium unilaterale and Microsorium pteropus.

Irregular meiotic behaviour suggestive of hybrid origin has been studied in Pteris ensiformis, Microsorium pteropus and Salvinia auriculata. Adiantum polyphyllum was found to be a sterile hybrid.

\section{Acknowledgement}

The author is deeply indebted to Prof. A. Abraham, Head of the Department of Botany and Dean, Faculty of Science, University of Kerala, for his guidance and encouragement. He is also thankful to the Ministry of Education, Government of India for the award of a Senior Research Scholarship during the tenure of which the work was carried out.

\section{References}

Abraham, A. and Ninan, C.A. 1954. Chromosomes of Ophioglossum reticulatum L. Curr. Sci. 23: $213-14$.

- and - 1958. Cytology of Isoetes. Ibid. 27:60-61.

- and - 1965. Morphological and cytological notes on Psilotum nudum (L.) Beauv. Caryologia 18: 537-539.

Abraham, A., et al. 1962. Studies on the cytology and phylogeny of the Pteridophytes: VII. Observations on one hundred species of South Indian Ferns. Jour. Indian Bot. Soc. 41: $339-421$.

Brownlie, G. 1961. Additional chromosome numbers in New Zealard Ferns. Trans. Roy. Soc. New Zealand, Bot., 1: 1-4.

Chiarugi, A. 1960. Tavole cromosomiche delle Pteridophyta. Caryologia 13: 27-150.

Fabbri, F. 1963. Primo supplemento alle "Tavole cromosomiche delle Pteridophyta" di Alberto Chiarugi. Caryologia 16: 237-335.

- 1965. Secondo supplemento alle "Tavole cromosomiche delle Pteridophyta" di Alberto Chiarugi. Caryologia 18: 675-731.

Kuriachan, P.I. 1963. Cytology of the genus Selaginella. Cytologia 28: 376-380.

- 1965. Cytology of Lycopodium cernuum L. Caryologia 18:633-636.

Ninan, C.A. 1955 . Cytology of Equisetum debile. Jour. Indian Bot. Soc. 34: 112-114.

- 1956a. Cytology of the Ophioglossaceae. Curr. Sci. 25: 161-162.

- 1956b. Studies on the cytology and phylogeny of the Pteridophytes. I. Observations on the Marattiaceae. Jour. Indian Bot. Soc. 35: 233-239.

- 1956c. Cytology of Psilotum nudum L. Cellule 57: 307-318.

- 1956d. Studies on the cytology and phylogeny of Pteridophytes. III. Observations on Osmunda regalis L. Jour. Indian Bot. Soc. 35: 248-251.

- 1956e. Studies on the cytology and phylogeny of Pteridophytes. IV. Systematic position of Ceratopteris thalictroides (L.) Brongn. Ibid. 35: 252-56. 
- 1958a. Studies on the cytology and phylogeny of the Pteridophytes. V. Observations on the Isoetaceae. Ibid. 37: 93-103.

- 1958b. Studies on the cytology and phylogeny of the Pteriodphytes. IT. Observations on the genus Lycopodium. Proc. Nat. Inst. Sci. India 24 B: 54-66.

- 1958c. Studies on the cytology and phylogeny of Pteridophytes. VI. Observations on the Ophioglossaceae. Cytologia 23: 291-316. 